\title{
Status, Challenges and Strategies of Dar es Salaam Seaport-Hinterland Connectivity
}

\author{
Msabaha Juma Mwendapole ${ }^{1, a}$ and Jin Zhihong ${ }^{2}$ \\ ${ }^{1-2}$ College of Transportation and Management, Dalian Maritime University High-Tech Zone District, No.1 Linghai Road, Liaoning Province, \\ Dalian City 116026, China
}

\begin{abstract}
Dar es Salaam seaport serving the Tanzania hinterland and other seven landlocked countries in East and Central Africa, The rapid economic growth of the hinterlands resulted to the increasing demand for overseas products from their country's residents, this create congestion at Dar es Salaam seaport. Due to this, the connection for the movement of commodities from seaport to its hinterland has noticeably very slow. A qualitative research methodology technique is used in this article to explore the status, challenges and strategies of Dar es Salaam seaporthinterland connectivity. The findings reveal that even though Dar es Salaam seaport is linked to the hinterland through both railway and road transport, but is hugely dependent on road transport. Regular tariffs increase for imports, insufficient number of trains and wagons connecting Dar es Salaam seaport, poor qualities of roads and railway infrastructures, congestion at the roads and the absence of new freight station are the main existing challenges in which significantly affect the smoothness of Dar es Salaam seaport-hinterland connectivity. Furthermore, the article proposes various enhancing strategies to combat named challenges. These strategies will be crucial to the government in decision making on how to develop and advancing Dar es Salaam seaport-hinterland connectivity.
\end{abstract}

\section{Introduction}

Recently, all major seaport of East Africa seeks to develop and enlarge its hinterland; consequently the level of seaport competition became stiff in this region. Dar es Salaam seaport now days onward is looking ahead to turn into the entire seaport hub for east and central Africa. In achieving this goal, it is very vital to retain existing seaport clients and also influencing new clients together with investors. Definitely, the additional number of seaport clients Dar es Salaam seaport can get, the more income it can generate. To becoming a busiest and leading seaport in the East and Central Africa regions, it is significant to ease the accessibility of Dar es Salaam seaport to its hinterland. Seaport is a significant interface infrastructure for whole transportation system, it's also a base for country industrial economy [1]. Seaport hinterland is fundamentally comprises of areas where seaport customers are coming from for the seaport to serves [2]. It is very true that the clients from hinterlands in the East and Central Africa are putting greater consideration into the disparity between their recent positions at the nearest seaports, the charges and facilities available and services offered by those seaports, however, they're access to the selected seaport is one among key concerns they consider in reaching decision-making. Quality for hinterland connections is the next mainly significant benchmark for seaport competitiveness behind the seaport cost factor [3]. To maintain its current hinterland clients and increasing its new clients and investors, Dar es Salaam seaport has to insure satisfactions of clients from its different services it offers. The economies of the Landlocked countries are mostly influenced by the increasing of freight services costs, moreover by exceeding irregularity in transit times [4].

Analysing Dar es Salaam seaport-hinterland connectivity is very vital for the Tanzania Port Authorities (TPA) as suggested strategies will solve various challenges also assisting the superior plan for the development of Dar es Salaam seaport. Seaport Logistics infrastructure development and constructions can sustain the economy of the regional and national as well [5]. The world economy and international trade depends on the multimodal corridors linking hinterlands with seaport gateways [6]. This research aims to analyse the status and recently challenges existing in Dar es Salaam seaporthinterland connectivity and providing some enhancing strategies for the resolution of the analysed challenges. A qualitative research methodology technique is used in this research, primary data collection tools such as interviews were carried out face to face with representatives of Tanzania Port Authorities (TPA), representative of ICDs and dry port in Tanzania, some regular clients of Dar es Salaam seaport, some officials from both railways facilitating central corridor namely Tanzania-Zambia Railway Authority (TAZARA) and Tanzania Railway Corporation (TRC), some representatives from a private company operating in Dar es Salaam seaport, a

\footnotetext{
${ }^{a}$ Corresponding author: mwendapole.msabaha@gmail.com
} 
representative from Tanzania Road Haulage, some officials of Tanzania Revenue Authority, some representative's offices for shipper and freight forwarders in Tanzania and other seaport stakeholders. Data used in this research were collected from interviews, distance calculator, official World Bank database website and the National Bureau of Statistics of Tanzania.

\section{Literature review}

Sustainable connection between seaport and landlocked countries is very important. The improvement of superior connections to hinterlands in various cases has been converted into significant because facilities of seaport can secure extra traffic [7]. Connectivity termed as node's linking ability in a network to each other. Connectivity for the seaport is a sub-network with interdependent elements in the transport network. Those elements including foreland, hinterland and seaport; the connectivity concerning about providing ability to seaport in handling movement between the hinterland and foreland [8]. From a seaport point of view, its hinterland is a region which having many of import/export associated businesses, which cannot be impeded because hinterlands varies according to commodities, transport mode, distance and time [9]. In order to increase countrys' trade, it is important to establish trade routes that combine 'the maritime seaport system into the network of multimodal transport so as to boost fluidity of trade, access to the market and incorporation into the entire network of the industrial [10]. Effective transport connections to the hinterland intended to donate in the absorption of those disadvantaged associated with geographical areas. As a result, wide-ranging expanded economic activities [11]. The presence of resourcefully transport infrastructure, reliable transport services and variety modal options are vital for convenient seaporthinterland connectivity.

Rivalry among seaports of similar regions in the globe became stiff, now days many researchers are interested with topics related to connectivity, supply chain management and seaport-hinterland. Nowadays, topics related to the connectivity of the seaport capture interest of many researchers and experts in the logistics field. The majority of Scholars who wrote articles on related titles have noted that development in intermodal transport for seaports and its hinterland should be well considered, so that thinking of seaport development necessarily means developing the seaport connectivity with its hinterlands. This is the first paper to provide full analysis concerning status and existing challenges in the Dar es Salaam seaport-hinterland connectivity using central corridor, and to provide tangible resolutions to this specific case. Shu-Ling Chen, Stephen Cahoon and Jagan Jeevan discussed the status, challenges and strategies of seaporthinterland connectivity of Malaysian seaport. Their findings discovered that, in Malaysian all rail and road transport linking main container seaports to their hinterlands but are highly road-dependent. They also described challenges to hinterland connectivity of Malaysia including, inadequate rail capacity and restricted facilities, imbalanced modal share road congestion and inland space constraints [12]. Hilde Meersman, Van de Voorde Eddy, Tom Pauwels, and Vanelslander Thierry, they explained the relationship existing between hinterland connections and seaport competition. Their conclusions were seaports must provide adequate maritime transport capacity, both in terms of transport options to hinterland together with commodities handling facilities. They considered hinterland logistics system in China's seaports as the case [13]. Khaliun Nasanjargal, Yan Chen and Pascal Kany Prud'ome Gamassa addressed Challenges and Strategies of Mongolia Connectivity to Tianjin port-hinterland. They agreed that, it is therefore important for both countries to ensure that connectivity from the port of Tianjin to Mongolia is more effective than it is now. This will enhance the support and relation between the two countries, also will assist China to keep retaining its position as the foremost partner of Mongolia, and thus will bring more revenue to both countries. The Tianjin port should advance in terms of facilities and pay more attention to services it provides throughout its connectivity to Mongolia [14]. Feng Sun, Yeru Shi and Xuefeng in their article, TOPSIS decision model proposed to help effectively pick the optimum plan for multimodal transport to the southwest from NingboZhoushan seaport. They finalized that railway transport is the best 20-foot container transport plan to Guiyang and Chengdu directly from Ningbo-Zhoushan seaport. Also road is the best 20-foot container transport plan to Kunming from Chongqing after commodities being arrived by rail from Ningbo-Zhoushan seaport [15]. Pascal Kany Gamassa Prud'ome and Yan Chen their article disclosed that the improvement of the connectivity to the hinterland will be contributed by teamwork between companies that make up the Abidjan porthinterland. Governments in the hinterland countries can also make a major contribution to improving connectivity to hinterland from seaport by constructing new railways and roads with the support of some international governments or investors from private institutions. They noted that creation of a department that will be responsible for organizing and managing, hinterland connectivity in the port of Abidjan and the building of new dry ports, will easy the provision of services to customers [16].

Moreover, Andrew Egba Ubogu in his article he appraised the capabilities of integrating road-rail network for Nigeria seaport-hinterland freights. He applied Geometric Mean analysis, frequency distribution and ttest for student's techniques to analyze collected data. The results of his article showed that the introduction of road-rail for inland bound commodities would be potentially save freight cost and time by $93.7 \%$ and $44.2 \%$ on the eastern and western flanks respectively, from the ports of Harcourt and Lagos [17]. Dr. Fred Mwirigi Mugambi and Charles Kipkoech Kotut also in their article Concentrated on the impact of transport connectivity and hinterland logistics of Mombasa port with the goal of defining how inefficiencies of the northern corridor affect the Mombasa seaport performance. Descriptive analysis was used to identify 
the current state of affairs and a study involved 58 respondents and stratified sampling approach used to hit the most representative, including port officials, KMA and $\mathrm{KSC}$, clearing and forwarding agents, logistics and transport organizations and port users. Researchers used interviews and questionnaires as tools for collecting data. Also Microsoft Excel used as software for data analysis and eventually evaluated and synthesize presentations for the intention of attaining goals. Research outcomes evident that the inefficiencies of hinterland transport has effects to Kenyan Ports Authorities (KPA) performance. inefficiencies of northern corridor also seems to contribute the slow freight uptake to hinterlands resulting to increase cargo dwell time and truck turn round time, this winded-up that the performance of seaports is significantly determined by indeed hinterland connectivity [18].

\section{Overview of Dar es Salaam seaport}

Tanzania is maritime country with the total area of $61,500 \mathrm{~km}^{2}$ sheltered by water bodies out of the total land area of $945,087 \mathrm{~km}^{2}$ [19]. The population of Tanzania has grown from 12.3 million after the independence census which conducted in1967 up to estimated 59.7 million in 2020 [20]. 1,424 km of Indian Ocean coastline comprises the three major seaports in Tanzania include Tanga, Mtwara and Dar es Salaam, seaports. These seaports support Tanzania economy by linking the inland transport system and the maritime network. Of significance, Dar es Salaam seaport is the country's most dominant seaport in which country's international sea trade that it handles accounts to more than $90 \%$. Dar es Salaam seaport serves as the major gateway for Tanzanian and hinterland shippers through the central corridor [21]. Dar es Salaam seaport exports an extensive range of commodities from Tanzania and landlocked countries including cotton lint, coffee, cashew nuts, tea, sisal fibers, tobacco, hides, skins, twine and mineral resources such as tanzanite and gold. The seaport of Dar es Salaam deliver varieties of imports that include machinery, chemicals, food grains, sugar, fertilizers, crude oil and petroleum products, spare parts, motor vehicles, textiles and plastic materials. Whereas, improved living condition of the countries' population contributed by large profit generated by these nations from exporting raw materials to foreign countries. Demand problem in these countries formed as the outcomes of the Growth Domestic Product net growth. By reason of increased consumption power, residents from these nations consume more overseas manufactured products. The majority of these products are transited via the seaport of Dar es Salaam.

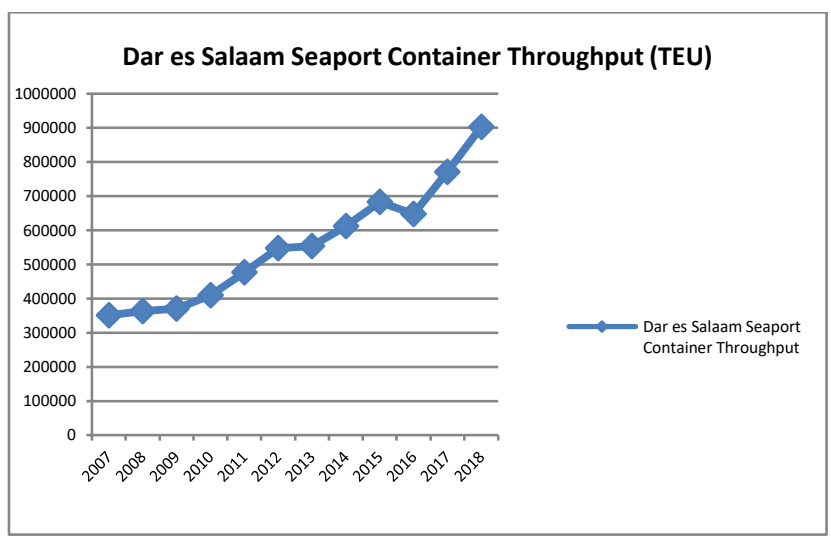

Source: World Bank (2019).

Figure 1. Dar es Salaam seaport container throughput (TEU) from 2007 to 2018

The above figure illustrates the Dar es Salaam Seaport Container Throughput (TEU) annually from 2007 to 2018. The volume of container throughput at Dar es Salaam seaport increased from 350,991 TEUs in 2007 to 903,000 TEUs in 2018. This is equal to an annual average rate rise of $11 \%$. If the volume of container throughput continues to increase at a similar pace, Dar es Salaam seaport will reach its current capacity of 1.2 millions TEUs in between 2020 and 2022. Transit cargoes account to 37\% of total cargo handled by Dar es Salaam seaport to neighbouring landlocked countries through the central corridor [22]. It is significant to note that up to 2018 container throughput at Dar es Salaam seaport was the most recent data available in the database of the World Bank by the moment this article was written.

\section{Performance status of Dar es Salaam seaport-hinterland connectivity}

This segment presents description on how Dar es Salaam seaport-hinterland connectivity is deliberated according to its infrastructures [23], together with the accessibility of transportation links to hinterlands.

\subsection{Rail transport connectivity status}

Tanzania's railway lines extend over 3,682 km, operated by two railway systems simply namely; TAZARA and TRC. The southern route stretched to Zambia from Dar es Salaam, run by Tanzania-Zambia Railways Authority with a total railway line of $1,860 \mathrm{~km}$, TAZARA line comprises $975 \mathrm{~km}$ in Tanzania itself and $885 \mathrm{~km}$ in Zambia all of $1.067 \mathrm{~m}$ gauge. The central route consist a total of 2,707 km with a gauge of $1 \mathrm{~m}$ run by the Tanzania Railways Corporation (TRC) [24]. Tanzania central rail line is the spine of the central corridor connecting the central, east, northern and the west on Lake Tanganyika in Kigoma region to Dar es Salaam seaport. Railway in Tanzania intended yearly to handle loads of not more than 5 million metric tons, presently it's carrying just less than $2 \%$ of its capacity [25]. Since early 2017 onward Tanzania started to construct standard gauge railways (1,435 millimeters), in which phase one of the project 
which having 300 track kilometres (205 km main line and $95 \mathrm{~km}$ for station sliding and crossing loop) from Dar es Salaam to Morogoro is yet completed and phase two of 422 track kilometers from Morogoro to MakutupolaDodoma (336 km of main line and $86 \mathrm{~km}$ for sliding station and crossing loops) until 01st April, 2020 was completed about 60 percent of the phase project. Both (first and second phases) of standard gauge railway network of 722 track kilometres from Dar es Salaam to Makutupola-Dodoma expected to be completed before the end of July, 2021 [26].

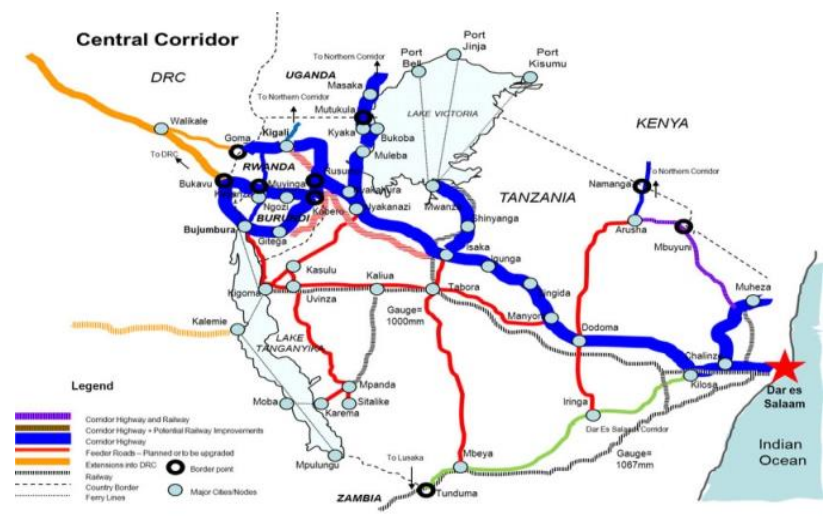

Source: Adapted from MTCW (2018)

Figure 2. Tanzania Central Corridor

\subsection{Road transport connectivity status}

Tanzania has a fairly well-developed road network of over 145,204.28 km of roads. About 10,382.07 km of roads are paved and $134,822.21 \mathrm{~km}$ are unpaved, of which $55 \%$ or half are maintained in fair or good condition. Whereas most of rural roads in Tanzania are still remain unpaved, and almost 85 percent are in very poor or poor condition. These $145,204.28 \mathrm{~km}$ of road network in Tanzania broken down as 36,257.97 kilometers are of regional roads, and 108,946.31 kilometers are of district, urban, and feeder roads. All trunk and regional roads in Tanzania are managed by TANROADS, while all village and city roads are managed by TARURA [27]. Road transport tops all other modes in Tanzania, carrying over $85 \%$ of total freight and $90 \%$ of passengers. Dar es Salaam Seaport is connected to hinterlands by road network, but the efficiency of the links needs improvement. In addition to the challenge, a great extent used road infrastructures and high congestion resulting to increasing in number of road accidents especially in congested regions closely to Dar es Salaam seaport [28]. Transporters those bypass highways or expressways and use restricted roads for heavy vehicles are major reasons for road accidents. Also trucks overloading for the aim of minimize costs, contributing to the roadway deterioration, fatigue cracking, rutting, and in some scenarios failure of the structures (generates in danger position for pedestrians, motorcyclists and bicyclists); and decreased ability of vehicle handling in emergency circumstances [29]. Mentioned challenges of road network in Tanzania may affect road connection efficiency between hinterlands and Dar es Salaam seaports, impact lies on the level of cargo clearance and agreed time of delivery in which the level of seaports attractiveness may be reduced [30].

Table 1: Imports Clearance by Mode of Transport at Dar es Salaam Seaport (DWT)

\begin{tabular}{|l|l|l|l|l|l|}
\hline Year/DWT & Road & $\%$ & Rail & $\%$ & $\begin{array}{l}\text { Annual } \\
\text { total }\end{array}$ \\
\hline 2012 & $3,831,551$ & 98.7 & 50,893 & 1.3 & $3,882,444$ \\
\hline 2013 & $3,178,291$ & 98.14 & 60,138 & 1.86 & $3,238,429$ \\
\hline 2014 & $4,938,091$ & 99.77 & 11,376 & 0.23 & $4,949,467$ \\
\hline 2015 & $5,932,883$ & 99.7 & 17,820 & 0.3 & $59,50,703$ \\
\hline 2016 & $6,326,921$ & 99.7 & 17,082 & 0.3 & $6,344,003$ \\
\hline 2017 & $5,998,611$ & 98.8 & 71,101 & 1.2 & $6,069,712$ \\
\hline 2018 & $6,162,766$ & 98.7 & 77,701 & 1.3 & $6,240,467$ \\
\hline $\begin{array}{l}\text { Grand } \\
\text { total }\end{array}$ & $\mathbf{3 6 , 3 6 9 , 1 1 4}$ & $\mathbf{9 9 . 2}$ & $\mathbf{3 0 6 , 1 1 1}$ & $\mathbf{0 . 8}$ & $\mathbf{3 6 , 6 7 5 , 2 2 5}$ \\
\hline
\end{tabular}

Source: Adapted from Ministry of work, transport and communication (2019).

From the figure above shows that the total number of imports cleared at Dar es Salam seaport from 2012 to 2018 were $36,675,225$ DWT, where by railway link cleared only 0.8 percent of all imports at Dar es Salaam seaport compared to 99.2 percent of imports cleared by road link. Seaport witnessed a low share of rail freight imports clearance from Dar $s$ Salaam seaports to hinterlands. Very low share of rail freight in Tanzania compared to share of road freight is quite similar to other third world countries, however extremely share of road freight associated with pollution, congestion, delays and energy consumption thus affecting the seaports competitiveness [31].

\section{Dar es Salaam seaport hinterland connectivity challenges}

In Africa, the inefficiency of the seaport services and supply chain is caused by pitiable markets connectivity, consequences of increased cost for infrastructures of land transport and poor quality of service offered [32]. The present challenges in the connectivity between Dar es Salaam seaport and its hinterland can be sub-divided into two parts: challenges which are existing in seaport itself and challenges of hinterland transportation.

Dar es Salaam seaport challenges consist of the challenges that are appearing in every process related to the departure and arrival of goods at seaport. Dar es Salaam seaport has a challenge on its draft capacity (it has $140 \mathrm{~m}$ wide channel for open sea way with only $10.7 \mathrm{~m}$ depth), so it cannot receive very big ships. Also seaport is getting rid of congestion challenge because it doubled its capacity while port infrastructures were not upgraded. Hence, Dar es Salaam seaport customers' spend a lot of time at seaport for cargo delivery. Some of its employees at Dar es Salaam seaport are not well conversant with knowledge of maritime field, thus diminish the quality of the service offered. Nowadays, seaports need highly developed technology system to be managed efficiently, but at Dar es Salaam seaport there are few highly talented employees in technology. Import tariffs at seaport also are high, so that sometimes customers not succeed to withdraw their commodities on 
time. Without a doubt, the long delay of the import documentation treatment significantly increases the demurrage fees. Surrounding areas of seaports are typically congested and most terrible of all roads they have poor infrastructures [33]. Truck drivers normally park on both road sides when they arriving at Dar es Salaam seaport main gate entrance, which creating city traffic jam. They normally park this way to wait for goods to be loaded or discharged since there is no parking space reserved for them.

Challenges of hinterland transportation, consists of the main challenges present in every transportation method that is used by a person to transport his goods from Dar es Salaam seaport to hinterland regions. It is well known that Dar es Salaam seaport is connected to hinterland regions by railway and road. Hence in this particular case, I may disclose challenges existing in both railway and road mode. Dar es Salaam seaport connected to hinterland regions by TRC and TAZARA railways, but Both TRC and TAZARA are in desperate need of investments to develop their infrastructure. TRC railroads were built at the turn of the century, and are of 1,000 mm gauge in size, and nearly $2,700 \mathrm{~km}$ in length. The rail network suffers from frequent washouts and unserviceable locomotives. Delay is created by many road stops and checkpoints, many checkpoint for checking truck's documents is also a challenge. Most of the time, truck drivers provide cash money to the police as bribes to proceed with their journey with no trouble. Increased final price of commodities sold on the marketplace of hinterland areas is directly caused by road briberies, making it costly for local consumers in the hinterland. There is heavy traffic congestion on the highways, which is so inconvenient and mostly due to poor road infrastructure, lack of interchangeable highways and narrow roads. Usually they overload trucks to carry more and reduce transport cost, which impact not only the vehicle's conditions, but also can cause accidents. Recently there are so many road accidents observed on these roads. Furthermore, even though Tanzania is a politically stable country, but there is a challenge of road armed robbery cases. Such are achieved by ex-rebels who own weapons and the stealing of money and goods from truck drivers dedicated to be their main occupation.

\section{Enhancing strategies for Dar es Salaam seaport-hinterland connectivity}

The findings have suggestions for strategies to improve the reliability and efficiency of the link between Dar es Salaam seaport and its hinterlands. The execution of these strategies can be easy with the grand spirit of the Tanzania's government through the Ministry of Works, Transport and Communication, Tanzania Ports Authorities, Tanzania Shipping Agency Corporation, and their various partners. The followings are recommended strategies.

\subsection{Develop a comprehensive transport network (seaport modal split strategies).}

\subsubsection{Promote modal shift by enhancing rail capacity}

Dar es Salaam seaports have become heavily dependent on road transport even though traffic congestion at seaport still exists. Limited numbers of train service, poor condition of wagons, single track systems and absence rail links in certain inland freight terminals are factors contributing to the restrictions of rail transport capacity in Tanzania. In view of the fact that rail transport costs are lower than road transport (findings based on interview), the use of rail transport would be favoured by both importers and exporters in the hinterlands if the efficiency of the rail network could be strengthened and thus they could achieve comparative advantages from a modal split in terms of time and expense. To tackle the challenge of an extremely unbalanced modal share of the multimodal freight transport network in Tanzania, the government introduced projects to develop rail infrastructure, such as the upgrading of the old rail and constructing a new standard rail gauge alongside the previous $1 \mathrm{~m}$ rail gauge. The new railway network will have the following features Axle load 35T, Gauge is 1,435 mm, Annual line capacity 17 million Tons, Freight train speed $120 \mathrm{Kph}$, Longest viaduct length $2.50 \mathrm{Km}$ within Dar es Salaam, Train length $2 \mathrm{~km}$ and Passenger train speed $160 \mathrm{Kph}$ [34]. In reality, the new rail network in Tanzania will have many pros. Firstly, the average train speed will reach $120 \mathrm{Kph}$ for freight and160 Kph for passenger train, this will be faster than the trucks speed. Secondly, relative to the cost of road freight, rail freight is cheaper. Thirdly, many customers in the hinterlands regions typically choose to transport commodities by train rather than by trucks as it is cheaper and quicker. This would help to avoid many check points that road having. But it is also important to control the time of the train service so the train can always depart on time. This will save time and will improve traffic, thus resulting to the generation of higher profits to customers.

\subsection{Strategies for road congestion improvements}

\subsubsection{Build new roads and develop the existing roads connecting Dar es Salaam seaport to its hinterland}

New roads that comply with worldwide standards can be constructed by the aid from foreign friends. Such roads will connect the hinterland regions to Dar es Salaam seaport. Most of the existing roads are very small and of low quality they should be developed. To speed up the delivery time of commodities from the Dar es Salaam seaport to its hinterland, providing wide roads would make it possible for drivers to reduce transit time.

\subsubsection{Create a management system special for trucks parking}

Trucks arriving at Dar es Salaam Seaport can be handled easily by developing a network that can handle them. Traffic jam at the entrance to the Dar es Salaam Seaport 
can be prevented by designing special parking lot. Trucks drivers should be able to verify the status of the commodities they receive online before arriving at the seaport, to know about when they will arrive at the seaport. It would help to save time that truck drivers normally spent in the terminal at the seaport. They can make more turns and earn more money by being quicker.

\subsubsection{Minimize checkpoints on the roads}

Decreasing the road checkpoints will radically cut down the checking fees charged to the truck drivers. The strategy would be to lower prices and increase sales instead of higher prices. Local police and customs authorities may also work together to harshly prosecute overloaded vehicles, thus protecting road infrastructure.

\subsection{Enhancing Strategies for seaport Development}

\subsubsection{Development of seaport facilities}

Dar es Salaam seaport should deepen its draft so that it can receive bigger ships. Dar es Salaam seaport should Construct two additional container berths (13 and 14) this will be a solution for the current congestion also will help to meet future growth in container handling at Dar es Salaam seaport. Also Dar es Salaam seaport should Strengthening/Upgrading existing berths 1-11 and modernisation of general cargo operations. Tanzania Ports Authority needs to continue and extend to employ more specialist terminal operators, as part of the expected expansion of the port.

\subsubsection{Reduce the seaports and customs fees}

The berthing fees are charged based on the GRT, though they should be specifically linked to the length of the vessel. The wharfage charge fee contained in the tariff book for non-containerized cargoes shall be paid on an ad valorem basis, resulting in a double "tax" on the value of the freight due to the charges of both the customs and port authority. In order to promote trade with other countries and maintain its economic growth, Tanzania really needs to reduce the import fees as it will help hinterland customers to purchase foreign goods at a lower price. This will encourage people to buy more foreign goods, leading to the increase of the number of imported goods, thus if more goods are imported, the government can get a higher revenue through import fees. Reducing the export fees will also help goods made in hinterland, to easily enter foreign markets, hence promoting the country economy.

\subsection{Enhancing capacity of inland freight facilities}

\subsubsection{Build a new container freight station at Kisarawe}

Construction of a new freight station in Kisarawe will be a possible solution. It will shuttle containers between the Dar es Salaam seaport and the freight station of Kisarawe by rail. Inland transport to/from the neighbouring landlocked countries will be by road and rail. Hence will assist to solve not only the road congestion challenges and decongesting Dar es Salaam seaport, but will also help to promote and develop the city by generating employment for country citizens and bring potential investors. This new container freight station will generate revenue which will contribute to improving the resident's life quality by constructing schools, hospitals, etc [35]. The suggested Kisarawe Freight Station (KFS) is to be located $11 \mathrm{~km}$ north of the town of Kisarawe and $2 \mathrm{~km}$ south of Morogoro Road, in order to offer a speedy access to this new freight station, highway roads should be built to access direct link to Morogoro road from freight station as shown in Figure 3 below.

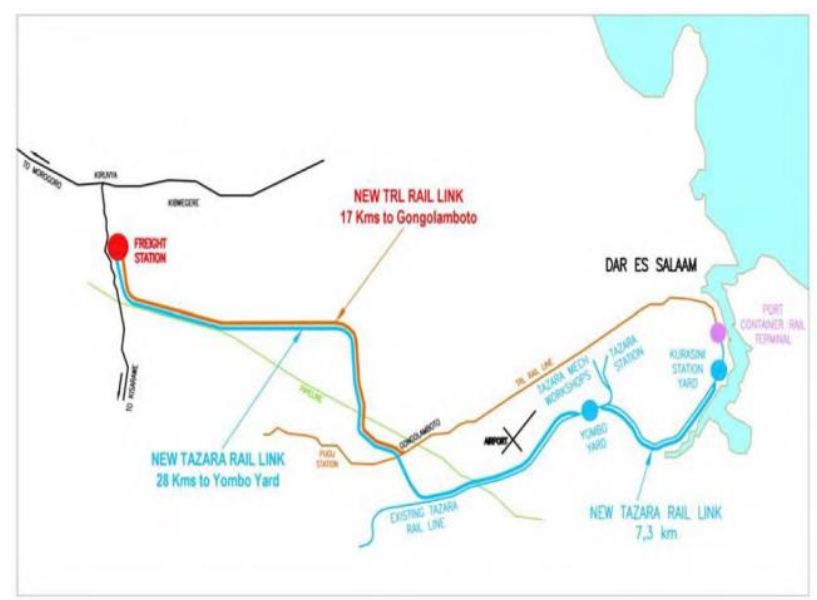

Source: Ecorys, 2011.

Figure 3: Suggested Kisarawe Freight Station

\subsection{Create a communication platform}

Dar es Salaam seaport required to establish communication platform in order to share information's with hinterland customers, customs offices, and trucks drivers. An online platform can be created through a website or by establishing of physical information centre which would enable the exchange of various related seaports information to customers, while at the same time taking care of their specific requests and concerns. The platform should display: date and time of arrival of the goods, their origin, destination country and city, the names of the sender and the recipient of the goods, the name of the logistic company in charge of collecting the goods, the kind of goods, the number of goods, etc. Through the platform of customers can check the status of their goods.

\subsection{Strengthen security in the central corridor}

Security in the central corridor of Tanzania should be strengthened by the respective administrations, as it is a very important corridor for the economy of the hinterland regions. Administrations generates huge profits through 
taxes charged by the truck drivers, hence police officers who will be maintaining protection along the road should be well motivated by giving them incentives.

\section{Conclusion}

This article overviewed the Dar es Salaam seaport and analysed the seaport-hinterland connectivity from the physical features point of view including freight facilities and transport connections. Findings exposed that even though Dar es Salaam seaport is connected to the hinterlands through both rail and road transport but currently is highly dependent on road. In this article it is pointed that it is necessary to develop comprehensive transport network (port modal split strategies) by enhancing rail capacity and improving road congestion, to enhancing capacity of inland freight facilities by building new freight station, to develop of seaport facilities, to reduce the seaports and customs fees, to create a communication platform for sharing information's, and to strengthen security in the central corridor. It is therefore great teamwork between the different entities will contribute to the improvement of the Dar es Salaam seaport - hinterland connectivity to become more efficient than it is now. Once the author proposed recommendations will be considered for the implementations, there is a great chance that in the coming years Dar es Salaam seaport will increase more customers from hinterland markets. This paper can be used as reference to future researchers, maritime experts, Tanzania ports Authorities and all the companies and institutions that are concerned in the Dar es Salaam seaport -hinterland connectivity.

\section{References}

1. Wang Jie, Zhang Huaqiang, "Analysis on hinterland segmentation in port project", International Conference on Engineering Computation, pp. 84-88, (2009)

2. Tetteh Evans, Hualong Yang, "Hinterland Demarcation Between Two West African Ports", International Conference on "Multidisciplinary Academic Research and Global Innovation, pp. 107116, (2015)

3. Raimonds Aronietis, Paresa Markianidou, Hilde Meersman, Tom Pauwels, Marc Pirenne, Eddy Van de Voorde, Thierry Vanelslander \& Ann Verhetsel, "Some effects of hinterland infrastructure pricing on port competitiveness: case of Antwerp", 12th WCTR, Lisbon, pp.1-23, (2010)

4. Jean-François Arvis, Gael Raballand \& JeanFrançois Marteau, "The Cost of Being Landlocked: Logistics Costs and Supply Chain Reliability", Social Science Electronic Publishing 28(2), pp. 1-81, (2010)

5. Wang Yang, Huang Wenwen, "Economic Analysis of Logistics Financial Management of Supply Chain System in Ports-Hinterland", International Conference on Electronic Commerce and Business Intelligence, pp. 207-212, (2009)
6. Dr. Fedele Iannone, "Dry ports and the extended gateway concept: port-hinterland container network design considerations and models under the shipper perspective", Ssrn Electronic Journal, pp. 1-26 (2013).

7. Jean-Paul Rodrigue, Theo Notteboom, "Challenges in the Maritime-Land Interface: Port Hinterlands and Regionalization", pp. 1-27, (2006).

8. Paflioti, P., Vitsounis, T.K., Tsamourgelis, I. and Bell, M.G.H., "Proceedings of container seaports connectivity": a concept analysis, International Forum on Shipping, Ports and Airports (IFSPA), Hong-Kong, (2014),

9. Notteboom, T., "Bundling of freight flows and hinterland network developments. The future of intermodal freight transport, operations, technology, design and Implementation". In: Konings, R., Priemus, H. and Nijkamp, P. (eds.), (2008)

10. Merk, O., LI, J., The Competitiveness of Global Port-Cities: the case of Hong Kong - China, OECD Regional Development Working Papers, 2013/16, OECDPublishing,https://ideas.repec.org/p/oec/govaa b/2013-16-en.html, (2013)

11. Bhattcharyay, B.N., "Seamless sustainable transport connectivity in Asia and the Pacific: prospects and challenges", International Economics and Economic Policy, Vol.9, No.2, pp. 147-189, (2012)

12. Shu-Ling Chen, Jagan Jeevan and Stephen Cahoon, "Malaysian Container Seaport-Hinterland Connectivity: Status, Challenges and Strategies", The Asian Jounal of Shipping and Logistics, pp.127137, (2016)

13. Hilde Meersman, Tom Pauwels, Eddy Van de Voorde \& Thierry Vanelslander, "The relation between port competition and hinterland connections the case of the 'Iron Rhine' and the 'Betuweroute", Conference proceedings of the International forum on Shipping, pp.1-23, (2008).

14. Khaliun Nasanjargal, Pascal Kany Prud'ome Gamassa and Yan Chen, "Tianjin Port-Hinterland Connectivity to Mongolia: Challenges and Strategies" International journal for developing country studies, Vol (8), No. 3, pp.71-78,(2018),.

15. Feng Sun, Xuefeng Wang, Lin Jin and Yeru Shi, "Improvement of Rail-sea Multimodal Transport with Dry Port Construction: Case Study of NingboZhoushan Port", Science Journal of Business and Management, pp.78-87, (2017),

16. Pascal Kany Prud'ome Gamassa and Yan Chen, "Challenges and Strategies of Abidjan PortHinterland Connectivity", MATEC Web of Conferences 124, pp.1-7, (2017)

17. Andrew Egba Ubogu, "The potentials of rail-road integration for port-hinterland freight transport in Nigeria", International Journal for Traffic \& Transport Engineering 1(2), pp. 89-107,(2011)

18. Charles Kipkoech Kotut, Dr. Fred Mwirigi Mugambi, "The Influence of Hinterland Transport Inefficiencies on the Performance of Ports-A Case Study of Kenya Ports Authority", International Journal of Science and Research, Vol. 3, no. 8, pp. 405- 417, (2014) 
19. African Natural Resources Centre of the African Development Bank, Review of Land Tenure Systems to Support the Creation of an Enabling Environment for Agricultural Transformation in Tanzania, (2016)

20. https://www.nbs.go.tz/index.php/en/

21. http://www.worldportsource.com/ports/commerce/T ZA_Port_of_Dar_es_Salaam_46.php

22. https://www.ports.go.tz/index.php/en/

23. Bhattcharyay, B.N., "Seamless sustainable transport connectivity in Asia and the Pacific: prospects and challenges". International Economics and Economic Policy, Vol.9, No.2, pp. 147-189, (2012)

24. http://www.mwtc.go.tz/uploads/publications/en 1528 210798Statistics\%20Publication_2016\%20FINAL $\% 20$-FINAL $\% 20$ place $\% 20 \mathrm{in} \% 20$ the $\% 20$ Website.pdf

25. http://trc.go.tz/reports

26. http://tarura.go.tz/reports

27. https://www.tanroads.go.tz/road-networks/regional

28. https://www.latra.go.tz/

29. Karim, M. R., Abdullah, A. S., Yamanaka, H., Abdullah, A. S., and Ramli, R., "Degree of Vehicle Overloading and its Implication on Road Safety in Developing Countries". Civil and Environmental Research, Vol.3, No.12, pp. 20-31, (2013)
30. Notteboom, T., "Bundling of freight flows and hinterland network developments. The future of intermodal freight transport, operations, technology, design and Implementation". In: Konings, R., Priemus, H. and Nijkamp, P. (eds.), (2008)

31. Wilmsmeier, G., Monios, J. and Rodrigue, J. P, "Drivers for Outside-In port hinterland integration in Latin America": The case of Veracruz, Mexico. Research in Transportation Business and Management, pp. 1-10, (2014)

32. African development report, "Connecting Ports to the Markets", AfricanBank, pp. 107- 153, (2010)

33. Regine Adele Ngono Fouda, Nana Darcis Romeo, Muhammad Azizi, S. Rick Fernandez, "Port Logistics in West and Central Africa: A Strategic Development under Globalization", Open Journal of Applied Sciences, Vol. 4, pp. 76-84, (2014)

34. Central Corridor, "Promoting efficiency in transport, logistics value chain and trade in the region", Annual performance Monitoring Reports, (2018)

35. Ecorys, Pre Feasibility Study, Review of PPP option and Optimum Option for Establishment of Kisarawe Freight Station. Rotterdam, February (2011) 